\title{
Ultrastructural and antioxidative changes in lupine embryo axes in response to salt stress
}

\author{
Łukasz Wojtyla*, Magda Grabsztunowicz, Małgorzata Garnczarska \\ Institute of Experimental Biology, Adam Mickiewicz University, Umultowska 89, 61-614 Poznań, Poland
}

\begin{abstract}
Embryo axes of lupine (Lupinus luteus L. 'Mister') were subjected to $0.1 \mathrm{M} \mathrm{NaCl}$ salt stress for 24 and $48 \mathrm{~h}$. The ultrastructure modification and adjustment of antioxidant enzymes activities and izoenzymes profiles were observed. In cells of lupine embryo axes grown for 48 hours in medium with $0.1 \mathrm{M} \mathrm{NaCl}$ mitochondria took the forked shape and bulges of the outer mitochondrial membranes appeared. Moreover, the inflating and swelling of rough endoplasmic reticulum (RER) lumen and fragmentation of RER were noticed. The level of $\mathrm{H}_{2} \mathrm{O}_{2}$ was higher in salt treated embryo axes after 24 hours and increase of thiobarbituric acid reactive substances was observed after both 24 and $48 \mathrm{~h}$ of salt treatment. Native gel electrophoresis showed increased intensities of bands for catalase isozymes in response to salt stress, whereas activity of catalase was higher only in embryo axes grown for $48 \mathrm{~h}$ in control conditions. Appearance of two new isoforms of ascorbate peroxidase was observed after $48 \mathrm{~h}$ only under control condition, however increased activities were stated for both control and salt-stress condition after 48 h. No changes in isozymes pattern for superoxide dismutase were observed, but significant decrease in superoxide dismutase activity was noticed in relation to time and salt stress. Possible role of these enzymes in salt stress tolerance is discussed. The $0.1 \mathrm{M}$ salt stress is regarded as a middle stress for lupine embryo axes and the efficiency of stress prevention mechanisms is proposed.
\end{abstract}

Keywords: salt stress, lupine, ultrastructure, antioxidant

\section{Introduction}

Salt stress is caused by accumulation of salts in the soil, mainly sodium chloride. The soil is classified as saline based on the electrical conductivity, the threshold is $4 \mathrm{dS} / \mathrm{m}$. This value corresponds approximately to a concentration of $40 \mathrm{mM}$ $\mathrm{NaCl}$, and generates an osmotic pressure of $-0.2 \mathrm{MPa}$ [1]. The initial soil salinity is a natural consequence of the formation of the soil from parent material with high salt content. Secondary salinization of soil can be both natural and anthropogenic. Human activity is contributing to an increase in soil salinity, mainly due to the use of inappropriate agricultural practices associated with irrigation of agricultural land. The main mistake is the use of water containing large amounts of salt to irrigation and insufficient drainage. Also, excessive and poorly balanced mineral fertilization may increase soil salinity [2]. Poor agricultural practices lead to soil degradation, which is particularly evident in areas where the rate of evapotranspiration is greater

* Corresponding author. Email: wojtylal@amu.edu.pl

Handling Editor: Grażyna Kłobus

This is an Open Access digital version of the article distributed under the terms of the Creative Commons Attribution 3.0 License (creativecommons.org/licenses/by/3.0/), which permits redistribution, commercial and non-commercial, provided that the article is properly cited. than rainfall, and soil granulometric properties hinder the leaching of ions. This situation leads to the accumulation of salts in the upper soil layers [3].

Soil salinity is very important factor limiting plant growth and yield and could be a reason of absence of the generative phase of ontogenetic development. Salinity leads to a number of changes in the functioning of plant cells related to mineral metabolism disorders, the cytotoxic effect of $\mathrm{Na}^{+}$and $\mathrm{Cl}^{-}$, reduction of water potential in the soil and in the cells and involves both osmotic and ionic stresses $[4,5]$. These two stresses occur in two phases. Firstly, a rapid response to the increase of external osmotic pressure and a parallel strong membrane depolarization caused by $\mathrm{Na}^{+}$uptake favors $\mathrm{K}^{+}$ efflux via depolarization-activated outward-rectifying $\mathrm{K}^{+}$channels take place during the first minutes [6]. At the same time, salinity-induced elevation in cytosolic $\mathrm{Ca}^{2+}$ leads to a dramatic raise in reactive oxygen species (ROS) level, resulting from $\left[\mathrm{Ca}^{2+}\right]$ cyt activation of NADPH oxidase via positive feedback mechanism [7]. Secondly, a salt specific response takes place due to accumulation and redistribution of $\mathrm{Na}^{+}$in cells. These effects depend on the salt concentrations and plant sensitivity to salt and can become visible after several days at high salinities. Salt injury is due to $\mathrm{Na}^{+}$or $\mathrm{Cl}^{-}$(or both) accumulating in plants to excessive levels, exceeding the ability of the cells to compartmentalize these ions in the vacuole. Ions then build up rapidly in the cytoplasm and inhibit enzymes activities, or they build up in the cell walls and dehydrate the cell [8]. The effective control of the oxidative damage induced by both effects, osmotic and ionic, might be critical for plant tolerance to high 
saline concentrations [5]. As the soil water potential decreases below the water potential in the root cells, water uptake by a plant is limited [1]. Mineral deficiency leads to disturbances of mineral nutrition, which further promote ionic stress caused by the excessive concentration of salt ions in the soil, mainly $\mathrm{Na}^{+}$ and $\mathrm{Cl}^{-}$[9]. Influx of $\mathrm{Na}^{+}$into the cells leads to an imbalance in the ion equilibrium, leading to destabilization of the membrane potential and facilitating the flow of ions according to transverse chemical gradient. $\mathrm{Na}^{+}$ions are toxic to enzymes, resulting in a reduction of their activity, which lead to an impairment of metabolic pathways. High concentration of $\mathrm{Na}^{+}$in the cell results in an osmotic imbalance, reduction in growth, restriction or inhibition of cell division and elongation and disruption of biological membranes. High concentrations of $\mathrm{Na}^{+}$in leaf cells lead to limitation of the capacity of photosynthesis, disturbances in protein synthesis and increased production of ROS. The consequences of these changes are yellowing and dieback of older leaves. Necrosis appears firstly on vertices and at the edge of the leaves [10,11]. A high concentration of chloride ions in the soil is also toxic to plant cells, limiting their growth and causing necrotic changes in the leaves [12]. Stress caused by salinity may also lead to PCD induction. It was shown by integrating the ultrastructural changes with observation of nuclear DNA fragmentation that strong salinity stress $(0.25$ and $0.5 \mathrm{M} \mathrm{NaCl}$ for $12 \mathrm{~h}$ ) leads to PCD execution in lupine embryo axes [13]. In order to protect cells from the toxic effects of $\mathrm{NaCl}$, plants have evolved different adaptive and protective mechanisms, which minimize the effects of stress and help to maintain homeostasis. In this study experiments were conducted on embryonic axes isolated from lupine seeds and grown in vitro on medium supplemented with $0.1 \mathrm{M} \mathrm{NaCl}$ for 24 and $48 \mathrm{~h}$. The aim of this work was to characterize antioxidant and ultrastructural responses of lupine embryo axes to salt stress.

\section{Material and methods}

\section{In vitro culture of embryonic axes}

Seeds of yellow lupine (Lupinus luteus L. 'Mister') were obtained from Poznań Plant Breeders Ltd. Seeds were surfacesterilized in $0.02 \%$ mercuric chloride for $5 \mathrm{~min}$ and in $0.5 \%$ sodium hypochlorite for 10 minutes, rinsed and allowed to imbibe for $24 \mathrm{~h}$ at $25^{\circ} \mathrm{C}$. Embryonic axes isolated from imbibed seeds were grown in vitro for 24 and $48 \mathrm{~h}$ on Heller [14] medium supplemented with $60 \mathrm{mM}$ sucrose [15] and with addition of $100 \mathrm{mM}$ sodium chloride or without $\mathrm{NaCl}$ (control). In vitro culture was carried out in darkness at $25^{\circ} \mathrm{C}$ on a gyratory shaker $(150 \mathrm{rpm})$.

\section{Malondialdehyde measurement}

Staining with Schiff's reagent is based on the formation of colored reaction product of the reagent with aldehyde moieties including malondialdehyde (MDA), that is one of the products of lipid peroxidation. Staining was performed according to Yamamoto et al. [16]. Lupine embryonic axes were placed for 30 minutes in Schiff's reagent (Sigma) and then were incubated in sulfite solution $\left(0.5 \% \mathrm{~K}_{2} \mathrm{~S}_{2} \mathrm{O}_{5}\right.$ in $\left.0.05 \mathrm{M} \mathrm{HCl}\right)$ for 30 minutes. Spectrophotometric measurement of thiobarbituric acid reactive substances (TBARS) was performed according to the method described by Floryszak-Wieczorek and Krzywański [17] with modification. Lupine embryonic axes $(0.25 \mathrm{~g})$ were ground in $5 \mathrm{ml}$ of water, then $5 \mathrm{ml} 0.5 \%$ TBA in $20 \%$ TCA was added. The mixture was heated for 30 minutes at $95^{\circ} \mathrm{C}$ in water bath, then cooled and centrifuged at $10000 \times g$ for 10 minutes at $4^{\circ} \mathrm{C}$. The absorbance was measured against blank at two wavelengths $\lambda=$ $532 \mathrm{~nm}$ and $\lambda=600 \mathrm{~nm}$. TBARS content was determined using a millimolar extinction coefficient $\varepsilon_{532-600} \mathrm{MDA}=155 \mathrm{mM}^{-1} \mathrm{~cm}^{-1}$.

\section{Hydrogen peroxide determination}

Spectrophotometric determination of hydrogen peroxide was performed based on the titanium $\left(\mathrm{Ti}^{4+}\right)$ method based on Becana et al. [18] as described by Arasimowicz et al. [19]. Lupine embryonic axes $(0.25 \mathrm{~g})$ were homogenized in $3 \mathrm{ml}$ of $100 \mathrm{mM}$ phosphate buffer $\mathrm{pH} 7.8$. The homogenate was centrifuged at $15000 \times g$ for $30 \mathrm{~min}$ at $4^{\circ} \mathrm{C}$. For spectrophotometric measurement the reactive mixture contained $100 \mathrm{mM}$ phosphate buffer $\mathrm{pH} 7.8$, plant extract and the titanium reagent consisting of 0.3 $\mathrm{mM} 4$-(2-pyridylazo)resorcinol and $0.3 \mathrm{mM}$ titanium potassium tartrate at the ratio 1:1. Absorbance was measured at $\lambda=508$ $\mathrm{nm}$ wavelength against a calibration curve prepared for the content of $\mathrm{H}_{2} \mathrm{O}_{2}$ from 0 to 100 nmole.

\section{Mitochondria isolation and respiratory measurement}

Mitochondrial fraction was obtained by differential centrifugation and purification of mitochondria by centrifugation in Percoll (Sigma) gradient according to Małecka et al. [20]. The embryo axes were homogenized in the isolation buffer containing 5\% BSA, $1 \mathrm{mM}$ EDTA, 1\% PVP, $0.35 \mathrm{M}$ sucrose, and $0.05 \mathrm{M}$ phosphate buffer ( $\mathrm{pH}$ 7.5). The homogenate was centrifuged for $10 \mathrm{~min}$ at $3000 \times g$. Then, the supernatant was centrifuged for $20 \mathrm{~min}$ at $15000 \times g$. The pellet containing mitochondria and peroxisomes was gently resuspended in a medium consisting of $0.3 \mathrm{M}$ mannitol, $0.2 \% \mathrm{BSA}, 1 \mathrm{mM}$ EDTA, and $20 \mathrm{mM}$ MOPS ( $\mathrm{pH}$ 7.2) and then purified in a continuous gradient formed by $24 \%$ (v/v) Percoll in $0.25 \mathrm{M}$ sucrose, $0.2 \%$ BSA and $20 \mathrm{mM}$ MOPS ( $\mathrm{pH}$ 7.2). The gradient was centrifuged at $40000 \times g$ for $40 \mathrm{~min}$ in fixed angle rotor with vacuum. Afterwards, the mitochondrial fraction was carefully collected and washed twice with a washing-buffer ( $0.35 \mathrm{M}$ sucrose, $20 \mathrm{mM}$ MOPS, $\mathrm{pH}$ 7.2) to remove Percoll and BSA. After 30 min centrifugation at $8000 \times g$ purified mitochondria were resuspended in the washing-buffer and used to estimate protein concentration [21] and respiratory measurement. The integrity and purity of mitochondrial fraction was confirmed by ultrastructure observation in transmission electron microscope. Oxygen consumption was measured in a Clark-type oxygen electrode in $0.8 \mathrm{~mL}$ of reaction medium consisting of $0.05 \mathrm{M}$ phosphate buffer pH 7.5 with $0.3 \mathrm{M}$ mannitol, $10 \mathrm{mM} \mathrm{KCl,} 5 \mathrm{mM} \mathrm{MgCl}_{2}$ and $0.2 \% \mathrm{BSA}$ and $0.5 \mathrm{mg}$ of mitochondrial protein. Respiration rate was measured in the presence of $10 \mathrm{mM}$ succinate as described by Małecka et al. [20]. Oxygen consumption of whole embryo axes was measured in a Clark-type oxygen electrode in $5 \mathrm{~mL}$ of $0.05 \mathrm{M}$ phosphate buffer $\mathrm{pH}$ 7.5. For each measurement three to five embryo axes were used.

\section{Native gel electrophoresis}

Protein extraction, electrophoresis and antioxidant enzyme visualization were done as described by Wojtyla et al. [22]. Extracts for electrophoretic assays of ascorbate peroxidase (APX), superoxide dismutase (SOD) and catalase (CAT) were prepared from plant materials homogenized in extraction buffer containing $50 \mathrm{mM}$ phosphate-potassium buffer ( $\mathrm{pH} 7.75$ ), $1 \mathrm{mM}$ EDTA, $1 \mathrm{mM}$ DTT, and 4\% PVP. The homogenates were centrifuged at $14000 \times g$ for $20 \mathrm{~min}$. Protein measurement was performed according to Bradford [21], using BSA as standard. 
Samples of extracts were electrophoresed in 10\% (APX, SOD) or $8 \%$ (CAT) polyacrylamide slab gels at $\mathrm{pH} 8.9$ under nondenaturing conditions according to Davis [23]. APX isoenzymes were detected in gels as reported by Mittler and Zilinskas [24]. SOD activity was detected on gels using the photochemical procedure of Beauchamp and Fridovich [25]. The different types of SOD were differentiated by performing the activity stains in gels previously incubated in $3 \mathrm{mmol} / \mathrm{L} \mathrm{KCN}$ or $5 \mathrm{mmol} / \mathrm{L}$ $\mathrm{H}_{2} \mathrm{O}_{2}$ as described by Asada et al. [26]. Isoenzymes of CAT were visualized on gels by the method of Woodbury et al. [27].

\section{Enzyme assays}

Extracts for determination of enzymes activities were prepared from $1 \mathrm{~g}$ of of lupine embryo axes grown in vitro with and without $0.1 \mathrm{M} \mathrm{NaCl}$ for 24 and 48 hours. The material was homogenized in $5 \mathrm{~cm}^{3}$ of extraction buffer, containing $50 \mathrm{mM}$ phosphate buffer (pH 7.5), 1 mM EDTA, 1 mM DTT, and 4\% PVP. The homogenates were centrifuged at $14000 \times g$ for $20 \mathrm{~min}$. Protein measurement was performed according to Bradford [21], using bovine serum albumin as standard. APX activity was determined as described by Garnczarska and Wojtyla [28] using a reaction mixture containing $50 \mathrm{mM}$ potassium phosphate buffer ( $\mathrm{pH}$ 7.0), 0.1 mM EDTA, $0.5 \mathrm{mM}$ ascorbate (AsA), $0.1 \mathrm{mM} \mathrm{H}_{2} \mathrm{O}_{2}$ and enzyme extract. Hydrogen peroxide dependent oxidation of AsA was followed by a decrease in the absorbance at $290 \mathrm{~nm}$ (coefficient of absorbance $2.8 \mathrm{mM}^{-1} \mathrm{~cm}^{-1}$ ). Due to oxidation of ascorbate without the presence of $\mathrm{H}_{2} \mathrm{O}_{2}$ by ascorbate oxidase, activity of ascorbate oxidase was subtracted [29]. The assay of SOD activity was based on the method of Beauchamp and Fridovich [25], which measures inhibition of the photochemical reduction of nitroblue tetrazolium (NBT) at $560 \mathrm{~nm}$. CAT activity was assayed according to the method of Aebi [30].

\section{Transmission electron microscope}

Preparation of embryo axes for transmission electron microscopy (TEM) was carried on according to Borek et al. [15]. Embryo axes were fixed in Karnowsky half-strength fixative [31], i.e. in a mixture of $4 \%$ glutaraldehyde and $4 \%$ paraformaldehyde at the ratio 1:1. Postfixation was conducted in $1 \%$ $\mathrm{OsO}_{4}$. The samples were stained in $2 \%$ aqueous solution of uranyl acetate. Dehydration was performed in a series of acetone solutions. The objects were embedded in epoxy resin of low viscosity [32]. Ultrathin sections were prepared on Ultrotome III (LKB), stained in 5\% uranyl acetate and $0.5 \%$ lead citrate and observed under the transmission electron microscope TEM-1200 Ex JEOL.

\section{Statistical analysis}

For all biochemical analysis three independent experiments were done. The statistical deviation of mean values was calculated using one-way analysis of variance (ANOVA) and TukeyKramer multiple comparison test. Means were considered as significantly different at $P<0.05$.

\section{Results}

\section{Oxidative stress caused by salinity}

The level and the intensity of oxidative stress in lupine embryo axes was specified according to the rate of lipid peroxidation measured spectrophotometrically with thiobarbituric acid and accumulation of hydrogen peroxide. The level of $\mathrm{H}_{2} \mathrm{O}_{2}$ was higher in salt treated embryo axes after 24 hour (Fig. 1a). The increase of TBARS, mainly MDA, was observed after both 24 and 48 h of salt treatment (Fig. 1b). Strong accumulation of TBARS after $48 \mathrm{~h}$ of salt stress well corresponded with staining reaction with Schiff reagent (Fig. 2).
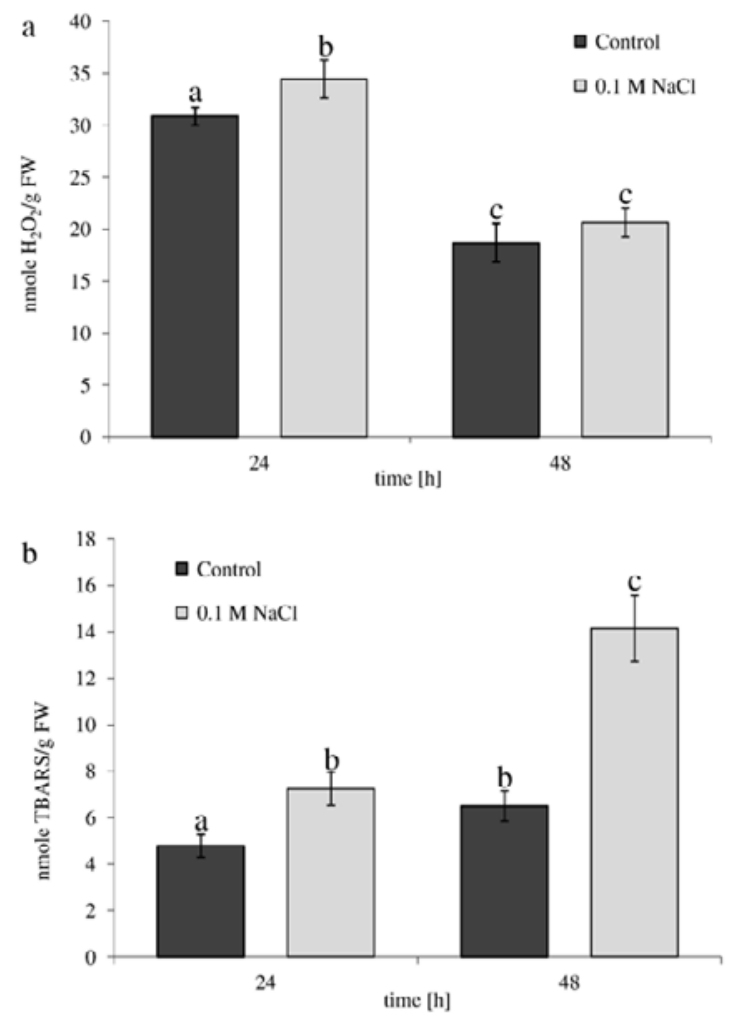

Fig. 1 Hydrogen peroxide and tiobarbituric acid reactive substances concentration in lupine embryo axes growing for 24 and 48 hours on $0.1 \mathrm{M} \mathrm{NaCl}$ and on control medium. a Hydrogen peroxide concentration. $\mathbf{b}$ Tiobarbituric acid reactive substances concentration. Data are given as mean $\pm S D$ of three independent experiments. Significant differences between data are marked with different letter in superscript.

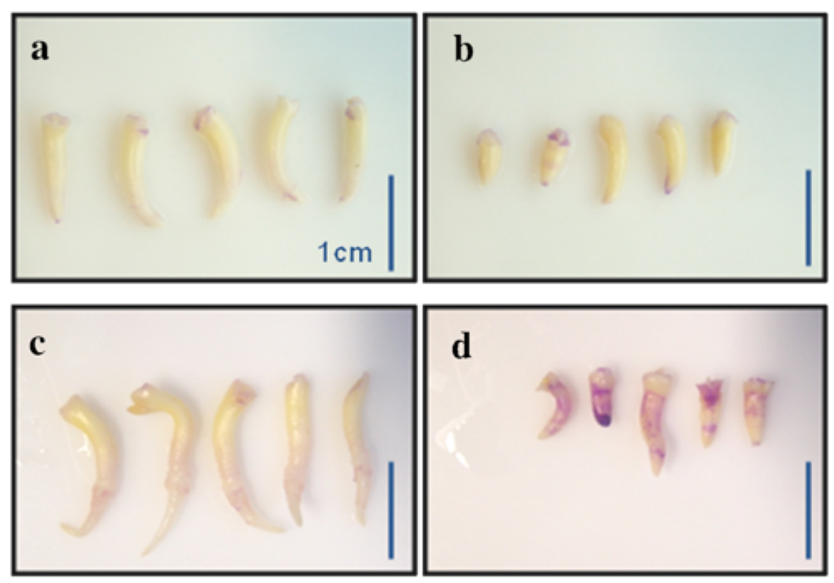

Fig. 2 Histochemical detection of lipid peroxidation caused by $0.1 \mathrm{M}$ $\mathrm{NaCl}$ in lupine embryo axes. The embryo axes were stained with Schiff's reagent. a Lupine embryo axes were grown for $24 \mathrm{~h}$ without $\mathrm{NaCl}$ (control condition). b Lupine embryo axes were grown for $24 \mathrm{~h}$ with $0.1 \mathrm{M} \mathrm{NaCl}$. c Lupine embryo axes were grown for $48 \mathrm{~h}$ without $\mathrm{NaCl}$ (control condition). d Lupine embryo axes were grown for $48 \mathrm{~h}$ with $0.1 \mathrm{M} \mathrm{NaCl}$. Bar in each graph indicates $1 \mathrm{~cm}$. 


\section{Native gel electrophoresis and activities of enzymes}

In addition to hydrogen peroxide and lipid peroxidation estimation the response of antioxidative enzymes: SOD, CAT and APX was examined. The data presented refer to electrophoretic patterns and activities of enzymes isolated from lupine embryo axes cultured in vitro for 24 and 48 hours with and without $0.1 \mathrm{M} \mathrm{NaCl}$. Native gel electrophoresis combined with specific activity staining revealed five isoforms of SOD in lupine embryo axes (Fig. 3a). Four observed forms (2-5) were identified as $\mathrm{Cu}, \mathrm{Zn}$-SOD and one (1) was identified

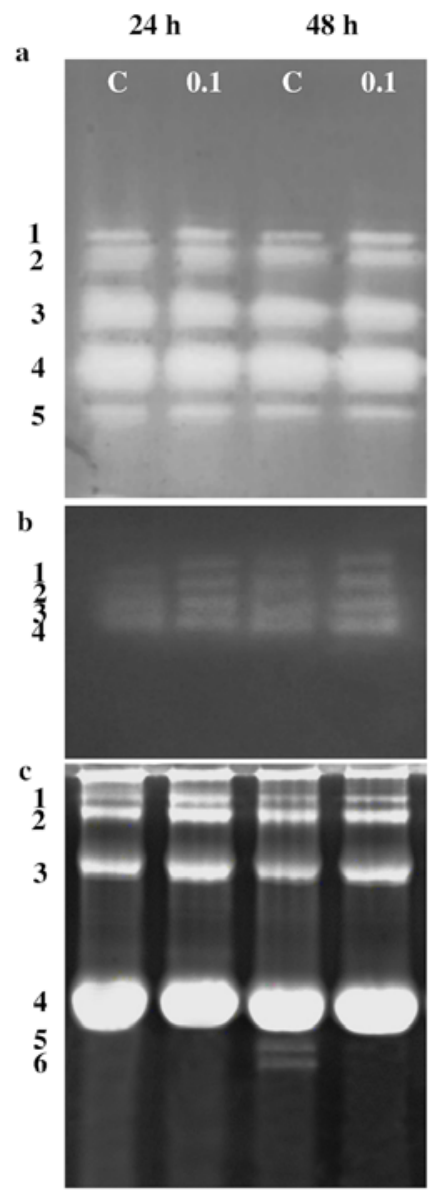

Fig. 3 Isoenzyme patterns of superoxide dismutase (a), catalase (b) and ascorbate peroxidase (c) in lupine embryo axes. The different isoforms are numbered from cathode to anode. For SOD $120 \mathrm{mg}$, for APX $100 \mathrm{mg}$ and for CAT $25 \mathrm{mg}$ proteins were loaded per each well. Similar results were obtained in at least free independent experiments. as Mn-SOD. All isoforms were present both in control and stressed embryo axes and no differences in intensity of staining were observed. However, spectrometric analysis of SOD activity revealed decreased activity in response to salt stress and in relation to time (Tab. 1). Gels stained for CAT activity revealed four isoforms in embryo axes (Fig. 3b). The intensity of the bands increased in relation to time of culture and was more pronounced in salt stressed embryo axes after both 24 and 48 hours. Activity of CAT measured spectrometrically was higher in lupine embryo axes growth in control condition after $48 \mathrm{~h}$ comparing with $24 \mathrm{~h}$, however no significant differences were observed between embryo axes growing in vitro for $24 \mathrm{~h}$ both in control and salt-stressed condition, as well as growing for $48 \mathrm{~h}$ in stress condition (Tab. 1). APX zymograms showed a total number of six forms (Fig. 3c). New isoforms of APX appeared in $48 \mathrm{~h}$ embryo axes grown under control condition (APX-5 and -6). Activity of APX was higher in lupine embryo axes growing with $0.1 \mathrm{M} \mathrm{NaCl}$, however no changes in activity were notice between control and salt-stressed axes (Tab. 1).

\section{Respiratory measurement}

The results of oxygen consumption by whole embryo axes are presented per gram of fresh weight (Tab. 2). Respiratory activity of both control and salt-treated embryonic axes grown for 48 hours was significantly lower as compared with axes cultured for 24 hours. However, embryonic axes cultured for 48 hours in medium with $0.1 \mathrm{M} \mathrm{NaCl}$ had a higher respiratory activity than control axes. Mitochondrial respiratory activity was higher in mitochondria isolated from embryo axes stressed for 24 hours than in control. After 48 hours oxygen consumption decreased both in stressed and control mitochondria and no differences between mitochondria isolated from stressed and control embryo axes were observed.

\section{Ultrastructure observation}

Changes in the ultrastructure were observed in the cells of the root meristem zone of lupine embryo axes cultured in a medium containing $0.1 \mathrm{M} \mathrm{NaCl}$ for 24 and 48 hours and compared with control (Fig. 4). No plasmolysis and changes in plasma membrane were noticed in response to salt stress after 24 and 48 hours. The ultrastructure of control cells showed typical morphology and there were no differences between 24 and 48 hours of culture. The observation was focused mainly on mitochondria. Mitochondria showed ellipse-shaped normal conformation with well-developed cristae. Endoplasmic reticulum was mainly rough, evenly distributed. After 24 hours of salt stress there were no differences in the amount, size and shape of the mitochondria from both control and salt-treated

Tab. 1 Activities of enzymes in lupine embryo axes.

\begin{tabular}{lcccc}
\hline & $\mathbf{2 4} \mathbf{h}$ control & $\mathbf{2 4} \mathbf{~ h ~ 0 . 1 ~} \mathbf{~ M ~ N a C l}$ & $\mathbf{4 8 ~ h ~ c o n t r o l}$ & $\mathbf{4 8 ~ h ~ 0 . 1 ~} \mathbf{~ M ~ N a C l}$ \\
\hline Superoxide dismutase (U/mg of protein) & $512.6 \pm 41.2^{\mathrm{a}}$ & $298.8 \pm 55.1^{\mathrm{b}}$ & $301.7 \pm 69.3^{\mathrm{b}}$ & $65.8 \pm 5.8^{\mathrm{c}}$ \\
Catalase ( $\mu$ katal/mg of protein) & $7.56 \pm 1.41^{\mathrm{a}}$ & $8.45 \pm 0.96^{\mathrm{a}}$ & $11.54 \pm 0.38^{\mathrm{b}}$ & $9.11 \pm 0.25^{\mathrm{a}}$ \\
Ascorbate peroxidase (nkatal/mg of protein) & $6.75 \pm 0.58^{\mathrm{a}}$ & $6.14 \pm 1.35^{\mathrm{a}}$ & $14.20 \pm 1.80^{\mathrm{b}}$ & $13.46 \pm 0.46^{\mathrm{b}}$ \\
\hline
\end{tabular}

Activities of SOD, CAT and APX in lupine embryo axes cultured in vitro with and without $0.1 \mathrm{M} \mathrm{NaCl}$ for 24 and $48 \mathrm{~h}$. Activity of SOD is expressed in units per mg of protein. One unit of SOD is defined as the amount of enzyme, which produces a 50\% inhibition of NBT reduction under the assay conditions. Activity of CAT is expressed in $\mu$ katal and APX in nkatal per mg of protein. One katal is the amount of enzyme that converts 1 mole of substrate per second. Data are given as mean $\pm S D$ of three independent experiments. Significant differences between data are marked with different letter in superscript. 
Tab. 2 Oxygen consumption by lupine embryo axes and isolated mitochondria.

\begin{tabular}{|c|c|c|c|c|}
\hline & $24 \mathrm{~h}$ control & 24 h $0.1 \mathrm{M} \mathrm{NaCl}$ & $48 \mathrm{~h}$ control & $48 \mathrm{~h} 0.1 \mathrm{M} \mathrm{NaCl}$ \\
\hline $\begin{array}{l}\text { Oxygen consumption by whole embryo axes } \\
\text { (nM O} \mathrm{O}_{2} / \mathrm{min} / \mathrm{g} \text { fresh weight) }\end{array}$ & $85.91 \pm 9.97^{\text {a }}$ & $88.44 \pm 26.42^{\mathrm{a}}$ & $31.64 \pm 4.63^{\mathrm{b}}$ & $56.44 \pm 8.04^{c}$ \\
\hline Oxygen consumption by isolated mitochondria & $39.42 \pm 2.60^{\text {a }}$ & $48.10 \pm 3.96^{\mathrm{b}}$ & $23.45 \pm 1.34^{\mathrm{c}}$ & $23.30 \pm 1.27^{\mathrm{c}}$ \\
\hline
\end{tabular}

( $\mathrm{nM} \mathrm{O}_{2} / \mathrm{min} / \mathrm{mg}$ of mitochondrial protein)
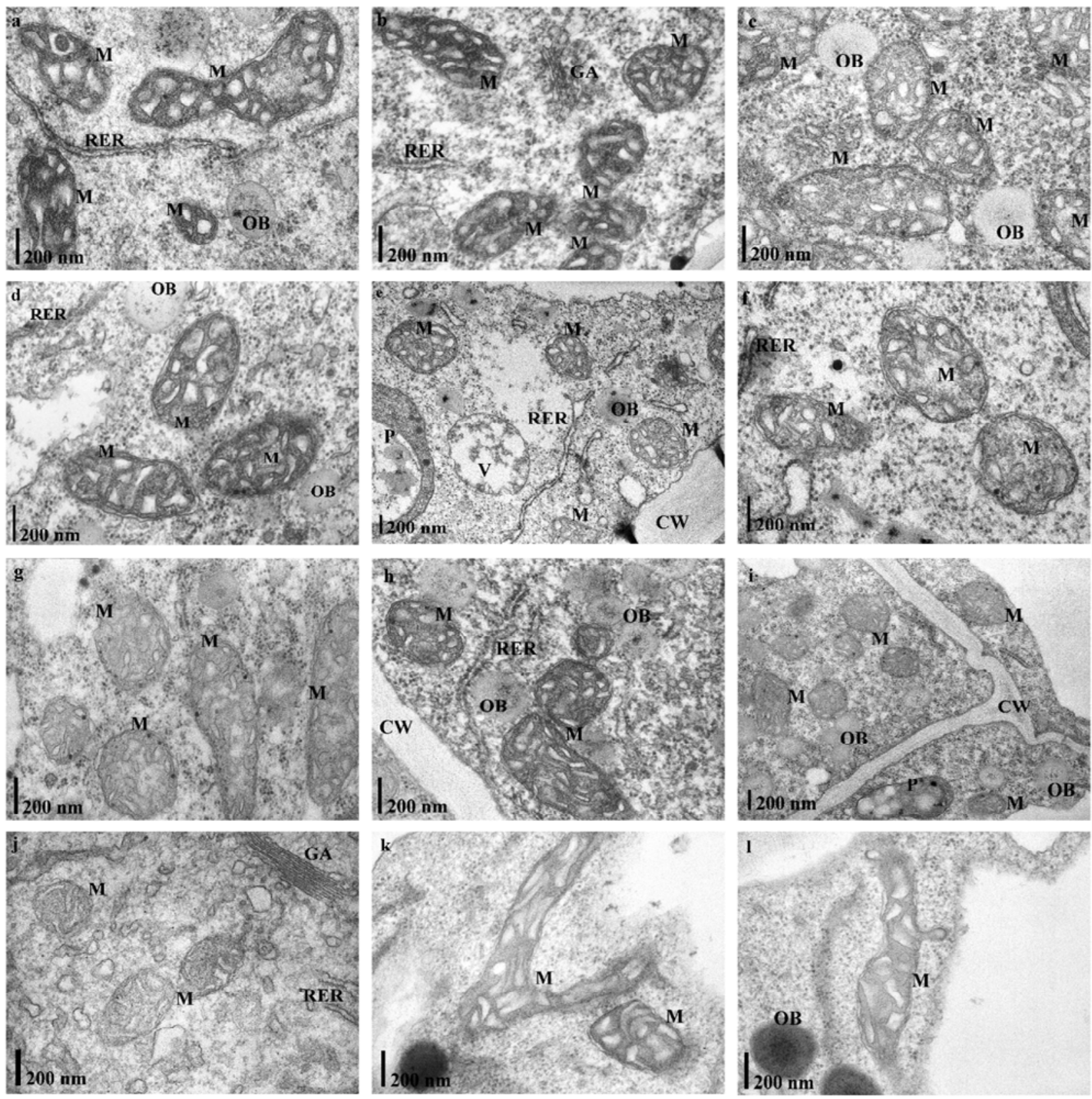

Fig. 4 Ultrastructure of radicle meristematic cells of lupine embryo axes. a-c Lupine embryo axes grown for $24 \mathrm{~h}$ on Heller medium without $\mathrm{NaCl}$ (control condition). d-f Lupine embryo axes grown for $24 \mathrm{~h}$ on Heller medium with $0.1 \mathrm{M} \mathrm{NaCl}$. g-i Lupine embryo axes grown for $48 \mathrm{~h}$ on Heller medium without $\mathrm{NaCl}$ (control condition). j-1 Lupine embryo axes grown for $48 \mathrm{~h}$ on Heller medium with $0.1 \mathrm{M} \mathrm{NaCl}$. CW - cell wall; GA - Golgi apparatus; M - mitochondrium; OB - oil body; P - plastid; RER - rough endoplasmic reticulum; V - vacuole.

embryo axes. In cells of embryonic axes cultured for 48 hours in medium with $0.1 \mathrm{M} \mathrm{NaCl}$ mitochondria took the forked shape and bulges of the outer mitochondrial membranes appeared. However, mitochondrial cristae organization remained as in control. Salt stress caused changes in rough endoplasmic reticulum (RER) ultrastructure. The inflating and swelling of RER lumen and fragmentation of endoplasmic reticulum were noticed. 


\section{Discussion}

The aim of this work was to assess the effect of salt stress on antioxidative enzymes and ultrastructure of lupine embryo axes. Thus embryo axes were grown in vitro in stable condition with and without sodium chloride for 24 and $48 \mathrm{~h}$. Lupine embryo axes were transferred into $0.1 \mathrm{M} \mathrm{NaCl}$ in a single step. Plant response to such way of $\mathrm{NaCl}$ application may be discussed as a salt shock, which is defined as an extreme form of salt stress, when plants are exposed suddenly to high level of salinity [33]. The main component of salt shock is osmotic shock or plasmolysis, especially in root cells [8]. In this experiment plasmolysis in embryo axes cells after 24 and $48 \mathrm{~h}$ of treatment was not observed. However, after $\mathrm{NaCl}$ application, plants usually achieve osmotic homeostasis during several hours or days depending on plant species and $\mathrm{NaCl}$ concentration [8].

Ultrastructural observation of plant mitochondria in cells exposed to different abiotic stresses revealed a number of changes in comparison with control cells. The most common changes include mitochondria swelling, a decrease in the number of cristae and gradual clarification of mitochondrial matrix [34,35]. Mitochondria are also known to be highly flexible in shape, volume, and surface area and their variability is a response to changes in environmental conditions. The occurrence of differently formed mitochondria could be induced by stress parameters or could result from changes in the mitochondrial function [36]. Changes in mitochondria shape and deformation of outer mitochondrial membrane were observed after $48 \mathrm{~h}$ of salt stress in lupine embryo axes. Cristae organization and mitochondrial interior in salt-treated embryo axes remained as in control. Changes in mitochondria ultrastructure in lupine embryo axes during salt stress were noticed after 12 hours of culture with 0.25 and $0.5 \mathrm{M} \mathrm{NaCl}$ [13]. Oxygen consumption by mitochondria isolated from $24 \mathrm{~h}$ salt stressed embryo axes was higher, compared with mitochondria isolated from control embryo axes. After $48 \mathrm{~h}$ no differences in oxygen uptake by mitochondria from control and salt treated axes were observed. However, whole embryo axes grown $48 \mathrm{~h}$ on $0.1 \mathrm{M} \mathrm{NaCl}$ showed higher oxygen consumption than control embryo axes. Oxygen consumption by both isolated mitochondria and whole embryo axes decreased in time, and was lower after $48 \mathrm{~h}$. Time-related decrease in oxygen consumption by embryo axes and mitochondria is typical for plants after completion of germination. A transient increase in oxygen demand was observed directly after seed coat rapture by embryonic axes in Pisum sativum [22]. The effect of salinity on mitochondrial respiration is often reported but the data are contradictory. There are published data showing that respiration rate increase in response to salt stress [37], while others show that it can decrease [38]. It is likely that these responses probably differ according to species, plant organ, developmental stage, and the severity of salinity treatment [39]. It is suggested that the ability to maintain respiratory homeostasis is linked to acquisition of salinity tolerance [39], whereas decreased rate of respiration is associated with loss of stress tolerance and could be regarded as one of the symptoms of programmed cell death [13]. Other characteristic feature observed in ultrastructure analysis is reorganization of RER. The RER lamellae became bulbous in response to salinity stress. Further, ribosomes were prominently attached to endoplasmic reticulum (ER) lamellae. Such prominent ER-ribosome complexes have previously been noted in response to water deficit, cold stress, oxygen deficiency, salt and high temperature stresses in various plant species which may possibly reflect induction of stress proteins often seen in response to stress conditions $[40,41]$.

Reactive oxygen species comprise both free radical and nonfree radical oxygen intermediates, which can trigger cell injury, and that is why we also focused on the main components of pro/anti-oxidative metabolism. Hydrogen peroxide is one of the major ROS and plays double role in plant metabolism during stress response. $\mathrm{H}_{2} \mathrm{O}_{2}$ production is not necessarily a symptom of cellular dysfunction but it could represent a signal for adjusting the machinery to the altered circumstances [42]. Increases in the concentration of ROS could be considered as an aspect of oxidative stress, but these also represent an active, beneficial biological reaction that is connected with high germination capacity and vigorous seedling development [43]. Changes in $\mathrm{H}_{2} \mathrm{O}_{2}$ accumulation influence the redox state of the cell [44]. The redox status plays a key role in regulation of metabolism and may influence enzyme activity and gene expression [45]. ROS, and particularly $\mathrm{H}_{2} \mathrm{O}_{2}$, besides induction of expression of many genes, might intervene in the cell-wall modification required for elongation of the radicle [46]. The level of $\mathrm{H}_{2} \mathrm{O}_{2}$ and accumulation of thiobarbituric acid reagent are commonly used as markers of oxidative stress. Oxidative stress accompanies salt stress and probably is one of the signals to modulate gene expression and to execute cell response to salt stress [47]. In lupine embryo axes increased level of $\mathrm{H}_{2} \mathrm{O}_{2}$ after 24 and higher level of thiobarbituric acid reactive substances pool after 24 and $48 \mathrm{~h}$ of salt treatment were observed. The increase of TBARS was transient, and after 72 hours it decreased to the level observed after $24 \mathrm{~h}$ of salt treatment (data not shown). The products of lipid peroxidation modify the physical properties of cell membranes, i.e. reduce the hydrophobicity of the interior of the lipid membrane, depolarize the membrane, disrupt the lipid membrane asymmetry, inhibit the activity of membrane enzyme, inhibit the activity of transport proteins, which in turn may result in loss of the integrity of the intracellular membranes and the plasma membrane. These processes can result in plant metabolism disturbance and even plant death [48]. Analysis of papers describing responses of salt-tolerant and sensitive varieties to salinity showed that the more tolerant varieties were characterized by lower level of lipid peroxidation and a lower increase of ROS than salt-sensitive varieties. Such observation was described in leaves of tomato [49,50], sugar [51], sesame [52], plantain [53] and rice [54] and in the roots of rice [55]. Increase in $\mathrm{H}_{2} \mathrm{O}_{2}$ and TBARS in response to salt stress was observed in wheat [56], rice [57] and tomato [58,59]. Regarding these results we conclude that lupine embryo axes experienced oxidative stress and a transient increase in TBARS was a consequence of salt shock occurring in first hours of $\mathrm{NaCl}$ treatment.

Oxidative stress can trigger a number of plant defense mechanisms enabling the removal of ROS, prevention and repair or elimination of damages of cell components. Antioxidative systems perform a crucial function in regulation of ROS concentration. This regulation might be achieved by changes in concentration of low molecular mass antioxidants, such as ascorbate and glutathione, and by different responses of antioxidative enzymatic systems, not only by changes in enzyme activities, but also by alteration in isoenzymatic patterns [22]. In this work, we focused on the enzymatic antioxidant system responsible for the removal of ROS, namely the determination of the isozyme patterns of selected antioxidant enzymes, which participate in $\mathrm{H}_{2} \mathrm{O}_{2}$ metabolism. APX is an 
enzyme that detoxifies peroxides such as hydrogen peroxide using ascorbate as a substrate. APX catalyses the transfer of electrons from ascorbate to a peroxide, producing dehydroascorbate and water [60]. CAT catalyzes the decomposition of hydrogen peroxide to water and oxygen [61]. SOD is an enzyme that dismutates superoxide into oxygen and hydrogen peroxide [62]. Electrophoretic analyses of antioxidative enzymes from lupine embryo axes showed increased activity of CAT under salt stress. New isoforms of APX appeared in lupine embryo axes after $48 \mathrm{~h}$ only under control condition, which may suggest decline in APX activity in relation to salt stress. The isoform patterns and activity of SOD remained at the same level in control and salt stressed lupine embryo axes. Increased activity and changes in isoforms composition of APX and SOD were stated for salt-treated rice [63]. Decrease in the activity of SOD and APX under the influence of salinity was observed in salt-sensitive seedlings of the variety of foxtail millet (Setaria italica L. cv. Lepakshi). In salinity tolerant variations (Setaria italica L. cv. Prasad) activity of SOD and APX increased under the influence of $\mathrm{NaCl}$ [64]. Similarly, in the plantain Plantago media SOD and CAT activities decreased under the influence of salinity, but the activity of APX did not change. The leaves of Plantago maritima - a species of plantain with a higher tolerance to salinity, showed increase in SOD, APX and CAT activities under salt-stressed conditions [53]. Comparative studies of different plant species showed that higher activity of antioxidant enzymes was noticed in varieties with higher tolerance to salinity. This situation was observed in the leaves of tomato $[49,50]$, beet [51], sesame [52] and rice [54,55]. Increased activity of CAT was observed in various stresses [65] and during pea [22] and lupine [66] seed germination. It is suggested that CAT plays a key role in salt stress acclimation [67] and is a key enzyme for seed repair against ageing ROS-induced damage during priming treatment [68].

Changes of CAT and APX activities suggest possible role of these enzymes in salt stress tolerance and maintaining the $\mathrm{H}_{2} \mathrm{O}_{2}$ pool at physiological level. Both enzymes seem to be efficient in ROS detoxification as no significant ultrastructural injuries were observed by transmission electron microscopy. The ability to maintain oxygen consumption at increased level together with all other results speak in favor that $0.1 \mathrm{M}$ $\mathrm{NaCl}$ treatment causes rather middle than severe salt stress for lupine embryo axes.

\section{Acknowledgments}

The presented research was funded by the Department of Plant Physiology, Adam Mickiewicz University and by Dean of Faculty of Biology, Adam Mickiewicz University, Grant PBWB-902/ 2008.

\section{Authors' contributions}

The following declarations about authors' contributions to the research have been made: performed experiments, analyzed the experimental data and drafted the manuscript: $Ł W$; performed experiments, prepared figure 3 and formatted literature index: MGr; designed and coordinated the study, analyzed the experimental data and was responsible for verification of the paper: MGa.

\section{References}

1. Munns R, Tester M. Mechanisms of salinity tolerance. Annu Rev Plant Biol. 2008;59(1):651-681. http://dx.doi.org/10.1146/annurev. arplant.59.032607.092911

2. Chinnusamy V, Jagendorf A, Zhu JK. Understanding and improving salt tolerance in plants. Crop Sci. 2005;45(2):437. http://dx.doi.org/10.2135/ cropsci2005.0437

3. Munns R. Genes and salt tolerance: bringing them together: Tansley review. New Phytol. 2005;167(3):645-663. http://dx.doi. org/10.1111/j.1469-8137.2005.01487.x

4. Tavakkoli E, Fatehi F, Coventry S, Rengasamy P, McDonald GK. Additive effects of $\mathrm{Na}^{+}$and $\mathrm{Cl}^{-}$ions on barley growth under salinity stress. J Exp Bot. 2011;62(6):2189-2203. http://dx.doi.org/10.1093/jxb/erq422

5. Hernandez M, Fernandez-Garcia N, Diaz-Vivancos P, Olmos E. A different role for hydrogen peroxide and the antioxidative system under short and long salt stress in Brassica oleracea roots. J Exp Bot. 2009;61(2):521-535. http://dx.doi.org/10.1093/jxb/erp321

6. Shabala S, Demidchik V, Shabala L, Cuin TA, Smith SJ, Miller AJ, et al. Extracellular $\mathrm{Ca}^{2+}$ ameliorates $\mathrm{NaCl}$-induced $\mathrm{K}^{+}$loss from Arabidopsis root and leaf cells by controlling plasma membrane $\mathrm{K}^{+}$-permeable channels. Plant Physiol. 2006;141(4):1653-1665. http://dx.doi.org/10.1104/pp.106.082388

7. Shabala S. Salinity and programmed cell death: unravelling mechanisms for ion specific signalling. J Exp Bot. 2009;60(3):709-712. http://dx.doi. org/10.1093/jxb/erp013

8. Munns R. Comparative physiology of salt and water stress. Plant Cell Env. 2002;25(2):239-250. http://dx.doi.org/10.1046/j.0016-8025.2001.00808.x

9. Tester $\mathrm{M}$, Davenport R. $\mathrm{Na}^{+}$tolerance and $\mathrm{Na}^{+}$transport in higher plants. Ann Bot. 2003;91(5):503-527. http://dx.doi.org/10.1093/aob/mcg058

10. Mahajan S, Tuteja N. Cold, salinity and drought stresses: an overview. Arch Biochem Biophys. 2005;444(2):139-158. http://dx.doi.org/10.1016/j. abb.2005.10.018

11. Tuteja N. Mechanisms of high salinity tolerance in plants. Methods Enzym. 2007;428:419-438. http://dx.doi.org/10.1016/S0076-6879(07)28024-3

12. White PJ, Broadley MR. Chloride in soils and its uptake and movement within the plant: a review. Ann Bot. 2001;88(6):967-988. http://dx.doi. org/10.1006/anbo.2001.1540

13. Wojtyla Ł, Rucińska-Sobkowiak R, Kubala S, Garnczarska M. Lupine embryo axes under salinity stress. I. Ultrastructural response. Acta Physiol Plant. 35(7):2219-2228. http://dx.doi.org/10.1007/s11738-013-1258-1

14. Heller R. Recherchessur la nutrition minerale des tissusvégétauxcultivé in vitro. Ann Sci Nat Bot. Biol. Végétale. 1953;14:1-223.

15. Borek S, Ratajczak W, Ratajczak L. Ultrastructural and enzymatic research on the role of sucrose in mobilization of storage lipids in germinating yellow lupine seeds. Plant Sci. 2006;170(3):441-452. http://dx.doi.org/10.1016/j. plantsci.2005.09.011

16. Yamamoto Y, Kobayashi Y, Matsumoto H. Lipid peroxidation is an early symptom triggered by aluminum, but not the primary cause of elongation inhibition in pea roots. Plant Physiol. 2001;125(1):199-208. http://dx.doi. org/10.1104/pp.125.1.199

17. Floryszak-Wieczorek J, Krzywański Z. Lipoxygenase activity and malonaldehyde content in potato tubers inoculated with Phytophthora infestans. Acta Physiol Plant. 1985;7:149-157.

18. Becana M, Aparicio-Tejo P, Irigoyen JJ, Sanchez-Diaz M. Some enzymes of hydrogen peroxide metabolism in leaves and root nodules of Medicago sativa. Plant Physiol. 82(4):1169-1171. http://dx.doi.org/10.1104/pp.82.4.1169

19. Arasimowicz M, Floryszak-Wieczorek J, Milczarek G, Jelonek T. Nitric oxide, induced by wounding, mediates redox regulation in pelargonium leaves. Plant Biol. 2009;11(5):650-663. http://dx.doi. org/10.1111/j.1438-8677.2008.00164.x

20. Małecka A, Jarmuszkiewicz W, Tomaszewska B. Antioxidative defense to lead stress in subcellular compartments of pearoot cells. Acta Biochim Pol. 2001;48(3):687-698. 
21. Bradford MM. A rapid and sensitive method for thequantitation of microgram of protein utilizing the principle ofprotein-dye binding. Anal Biochem. 1976;72:248-254. http://dx.doi.org/10.1006/abio.1976.9999

22. Wojtyla $€$, Garnczarska M, Zalewski T, Bednarski W, Ratajczak L, Jurga S. A comparative study of water distribution, freeradical production and activation of antioxidativemetabolism in germinating pea seeds. J Plant Physiol. 2006;163:1207-1220. http://dx.doi.org/10.1016/j.jplph.2006.06.014

23. Davis BJ. Disc electrophoresis - II: method and applicationto human serum proteins. Ann N Acad Sci. 1964;121(2):404-427. http://dx.doi. org/10.1111/j.1749-6632.1964.tb14213.x

24. Mittler R, Zilinskas BA. Detection of ascorbate peroxidaseactivity in native gels by inhibition of the ascorbate dependent reduction of nitrobluetetrazolium. Anal Biochem. 1993;212(2):540-546. http://dx.doi.org/10.1006/ abio.1993.1366

25. Beauchamp CH, Fridovich I. Superoxide dismutase: improved assays and an assay applicable to acrylamide gels. Anal Biochem. 1971;44(1):276-287. http://dx.doi.org/10.1016/0003-2697(71)90370-8

26. Asada K, Yoshikawa K, Takahashi M, Maeda Y, Enmanji K. Superoxide dismutase from a blue-green alga, Plectonema boryanum. J Biol Chem. 1975;250:2801-2807.

27. Woodbury W, Spencer AK, Stahmann MA. An improved procedure using ferricyanide for detecting catalase isozymes. Anal Biochem. 1971;44(1):301-305. http://dx.doi.org/10.1016/0003-2697(71)90375-7

28. Garnczarska M, Wojtyla $€$. Ascorbate and glutathione metabolism in embryo axes and cotyledons of germinating lupine seeds. Biol Plant. 2008;52:681-686. http://dx.doi.org/10.1007/s10535-008-0131-3

29. Nakano Y, Asada K. Purification of ascorbate peroxidase in spinach chloroplasts; its inactivation in ascorbate-depleted medium and reactivation by monodehdroascorbate radical. Plant Cell Physiol. 1987;28:131-140.

30. Aebi H. Catalase in vitro. Methods Enzym. 1984;105:121-126. http:// dx.doi.org/10.1016/S0076-6879(84)05016-3

31. Karnowsky MJ. A formaldehyde-glutaraldehyde fixative of high osmolarity for use in electron microscopy. J Cell Biol. 1965;27:137-138.

32. Spurr AR. A low viscosity epoxy resin embedding medium forelectron microscopy. J Ultrastruct. Res. 1969;26:31-43. http://dx.doi.org/10.1016/ S0022-5320(69)90033-1

33. Shavrukov Y. Salt stress or salt shock: which genes are we studying? J Exp Bot. 2013;64(1):119-127. http://dx.doi.org/10.1093/jxb/ers316

34. Vartapetian BB. Functional electron microscopy in studies of plant response and adaptation to anaerobic stress. Ann Bot. 2003;91(2):155-172. http:// dx.doi.org/10.1093/aob/mcf244

35. Vassileva V, Simova-Stoilova L, Demirevska K, Feller U. Variety-specific response of wheat (Triticum aestivum $\mathrm{L}$.) leaf mitochondria to drought stress. J Plant Res. 2009;122:445-454. http://dx.doi.org/10.1007/ s10265-009-0225-9

36. Zellnig G, Zechmann B, Perktold A. Morphological and quantitative data of plastids and mitochondria within drought-stressed spinach leaves. Protoplasma. 223:221-227. http://dx.doi.org/10.1007/s00709-003-0034-2

37. Livne A, Levin N. Tissue respiration and mitochondrial oxidative phosphorylation of NaCl-treated pea seedlings. Plant Physiol. 1967;42(3):407414. http://dx.doi.org/10.1104/pp.42.3.407

38. Jolivet Y, Pireaux JC, Dizengremel P. Changes in properties of barley leaf mitochondria isolated from NaCl-treated plants. Plant Physiol. 1990;94(2):641-646. http://dx.doi.org/10.1104/pp.94.2.641

39. Jacoby RP, Millar AH, Taylor NL. Wheat mitochondrial proteomes provide new links between antioxidant defense andplant salinity tolerance. J Prot Res. 2010;9(12):6595-6604. http://dx.doi.org/10.1021/pr1007834

40. Ciamporova M, Mistrik I. The ultrastructural response of root cells to stressful conditions. Env Exp Bot. 1993;33(1):11-26. http://dx.doi. org/10.1016/0098-8472(93)90052-H

41. Pareek A, Singla SL. Short-term salinity and high temperature stressassociated ultrastructural alterations in young leaf cells of Oryza sativa L. Ann Bot. 1997;80(5):629-639.
42. Jaspers P, Kangasjärvi J. Reactive oxygen species in abiotic stress signaling. Physiol Plant. 2010;138(4):405-413. http://dx.doi. org/10.1111/j.1399-3054.2009.01321.x

43. Schopfer P, Plachy C, Frahry G. Release of reactive oxygen intermediates (superoxide radicals, hydrogen peroxide, and hydroxyl radicals) and peroxidase in germinating radish seeds controlled by light, gibberellin, and abscisic acid. Plant Physiol. 2001;125(4):1591-1602. http://dx.doi. org/10.1104/pp.125.4.1591

44. Kuźniak E, Urbanek $\mathrm{H}$. The involvement of hydrogen peroxide in plant responses to stresses. Acta Physiol Plant. 2000;22(2):195-203. http://dx.doi. org/10.1007/s11738-000-0076-4

45. Kornas A, Kuźniak E, Ślesak I, Miszalski Z. The key role of the redox status in regulation of metabolism in photosynthesizing organisms. Acta Biochim Pol. 2010;57(2):143-151.

46. Gapper C, Dolan L. Control of plant development by reactive oxygen species. Plant Physiol. 2006;141(2):341-345. http://dx.doi.org/10.1104/ pp.106.079079

47. Rubio MC, Bustos-Sanmamed P, Clemente MR, Becana M. Effects of salt stress on the expression of antioxidant genes and proteins in the model legume Lotus japonicus. New Phytol. 2009;181(4):851-859. http://dx.doi. org/10.1111/j.1469-8137.2008.02718.x

48. Gill SS, Tuteja N. Reactive oxygen species and antioxidant machinery in abiotic stress tolerance in crop plants. Plant Physiol Biochem. 2010;48(12):909-930. http://dx.doi.org/10.1016/j.plaphy.2010.08.016

49. Shalata A, Tal M. The effect of salt stress on lipid peroxidation and antioxidants in the leaf of the cultivated tomato and its wild salt-tolerant relative Lycopersicon pennellii. Physiol Plant. 1998;104(2):169-174. http://dx.doi. org/10.1034/j.1399-3054.1998.1040204.x

50. Koca H, Ozdemir F, Turkan İ. Effect of salt stress on lipid peroxidation and superoxide dismutase and peroxidase activities of Lycopersicon esculentum and L. pennellii. Biol Plant. 2006;50(4):745-748. http://dx.doi.org/10.1007/ s10535-006-0121-2

51. Bor M, Özdemir F, Türkan İ. The effect of salt stress on lipid peroxidation and antioxidants in leaves of sugar beet Beta vulgaris L. and wild beet Beta maritima L. Plant Sci. 2003;164(1):77-84. http://dx.doi.org/10.1016/ S0168-9452(02)00338-2

52. Koca H, Bor M, Özdemir F, Fridovich I. The effect of salt stress on lipid peroxidation, antioxidative enzymes and proline content of sesame cultivars. Env Exp Bot. 2007;60(3):344-351. http://dx.doi.org/10.1016/j. envexpbot.2006.12.005

53. Hediye Sekmen A, Türkan İ, Takio S. Differential responses of antioxidative enzymes and lipid peroxidation to salt stress in salt-tolerant Plantago maritima and salt-sensitive Plantago media. Physiol Plant. 2007;131(3):399-411. http://dx.doi.org/10.1111/j.1399-3054.2007.00970.x

54. Vaidyanathan H, Sivakumar P, Chakrabarty R, Thomas G. Scavenging of reactive oxygen species in $\mathrm{NaCl}$-stressed rice (Oryza sativa L.) differential response in salt-tolerant and sensitive varieties. Plant Sci. 2003;165(6):1411-1418. http://dx.doi.org/10.1016/j.plantsci.2003.08.005

55. Demiral T, Turkan İ. Comparative lipid peroxidation, antioxidant defense systems and proline content in roots of two rice cultivars differing in salt tolerance. Env Exp Bot. 2005;53(3):247-257. http://dx.doi.org/10.1016/j. envexpbot.2004.03.017

56. Sairam RK, Srivastava GC. Changes in antioxidant activity in sub-cellular fractions of tolerant and susceptible wheat genotypes in response to long term salt stress. Plant Sci. 2002;162(6):897-904. http://dx.doi.org/10.1016/ S0168-9452(02)00037-7

57. Khan MH, Singha KLB, Panda SK. Changes in antioxidant levels in Oryza sativa L. roots subjected to NaCl-salinity stress. Acta Physiol Plant. 2002;24(2):145-148. http://dx.doi.org/10.1007/s11738-002-0004-x

58. Mittova V, Tal M, Volokita M, Guy M. Up-regulation of the leaf mitochondrial and peroxisomal antioxidative systems in response to salt-induced oxidative stress in the wild salt-tolerant tomato species Lycopersicon pennellii. Plant Cell Env. 2003;26(6):845-856. http://dx.doi. 
org/10.1046/j.1365-3040.2003.01016.x

59. Mittova V, Guy M, Tal M, Volokita M. Salinity up-regulates the antioxidative system in root mitochondria and peroxisomes of the wild salt-tolerant tomato species Lycopersicon pennellii. J Exp Bot. 2004;55(399):1105-1113. http://dx.doi.org/10.1093/jxb/erh113

60. Raven EL. Peroxidase-catalyzed oxidation of ascorbate structural, spectroscopic and mechanistic correlations in ascorbate peroxidase. In: Holzenburg A, Scrutton NS, editors. Enzyme-catalyzed electron and radical transfer. New York, NY: Springer; 2002. p. 317-349. (Subcellular biochemistry). http://dx.doi.org/10.1007/0-306-46828-X_10

61. Chelikani P, Fita I, Loewen PC. Diversity of structures and properties among catalases. Cell Mol Life Sci. 2004;61(2):192-208. http://dx.doi. org/10.1007/s00018-003-3206-5

62. Kliebenstein DJ, Monde RA, Last RL. Superoxide dismutase in Arabidopsis: an eclectic enzyme family with disparate regulation and protein localization. Plant Physiol. 1998;118(2):637-650. http://dx.doi.org/10.1104/pp.118.2.637

63. Lee DH, Kim YS, Lee CB. The inductive responses of the antioxidant enzymes by salt stress in the rice (Oryza sativa L.). J Plant Physiol. 2001;158(6):737-745. http://dx.doi.org/10.1078/0176-1617-00174
64. Sreenivasulu N, Grimm B, Wobus U, Weschke W. Differential response of antioxidant compounds to salinity stress in salt-tolerant and salt-sensitive seedlings of foxtail millet (Setaria italica). Physiol Plant. 2000;109(4):435442. http://dx.doi.org/10.1034/j.1399-3054.2000.100410.x

65. Mhamdi A, Queval G, Chaouch S, Vanderauwera S, Breusegem FV, Noctor G. Catalase function in plants: a focus on Arabidopsis mutants as stress-mimic models. J Exp Bot. 2010;61(15):4197-4220. http://dx.doi. org/10.1093/jxb/erq282

66. Garnczarska M, Wojtyla $Ł$. Differential response of antioxidative enzymes in embryonic axes and cotyledons of germinating lupine seeds. Acta Physiol Plant. 2008;30(4):427-432. http://dx.doi.org/10.1007/s11738-008-0138-6

67. Gondim FA, Gomes-Filho E, Costa JH, Mendes Alencar NL, Prisco JT. Catalase plays a key role in salt stress acclimation induced by hydrogen peroxide pretreatment in maize. Plant Physiol Biochem. 2012;56:62-71. http://dx.doi.org/10.1016/j.plaphy.2012.04.012

68. Kibinza S, Bazin J, Bailly C, Farrant JM, Corbineau F, El-MaaroufBouteau H. Catalase is a key enzyme in seed recovery from ageing during priming. Plant Sci. 2011;181(3):309-315. http://dx.doi.org/10.1016/j. plantsci.2011.06.003 